\title{
Allocation of Groundwater Recharge Zones in a Rural and Semi-Arid Region for Sustainable Water Management: Case Study in Guadalupe Valley, Mexico
}

\author{
Juan Alejandro Saiz-Rodríguez, Marcelo A. Lomeli Banda, Carlos Salazar-Briones, \\ José Mizael Ruiz-Gibert and Alejandro Mungaray-Moctezuma * \\ Faculty of Engineering, Universidad Autónoma de Baja California, Mexicali, Blvd. Benito Juárez, S/N, \\ Mexicali C.P. 21280, México \\ * Correspondence: alejandro.mungaray@uabc.edu.mx; Tel.: +52-686-566-42-70
}

Received: 30 May 2019; Accepted: 26 July 2019; Published: 31 July 2019

check for updates

\begin{abstract}
Around the world, groundwater constitutes approximately $94 \%$ of the total volume of freshwater, providing a wide range of economic and environmental services. In Baja California, Mexico, groundwater provides around $60 \%$ of the required demand and has become an essential source for agriculture, industry and domestic use. Particularly, in the Guadalupe Valley, in the municipality of Ensenada, the development of diverse activities depends on the water stored in the aquifer. Among these activities, agroindustry stands out; due to its high value, it represents a regional development factor. The objective of this research consisted of identifying potential aquifer recharge sites as tools for the planning process for regional socio-economic development. The study consisted of four fundamental parts: (1) Compilation and identification of entry data of the recharge model; (2) identification and evaluation of the sites that have a greater or lesser capacity of water recharge, using a geographic information system (GIS); (3) comparison of the model results with the piezometric data of two wells in the study area and their relationship with precipitation events; (4) finally, the development planning instruments of the study area were identified, and the relevance of the present study as a planning tool was evaluated. The results obtained showed that $16.31 \%$ and $3.64 \%$ of the area presents a high and very high recharge potential, respectively. This article is useful for the authorities and users to develop projects for aquifer recharge in the Guadalupe Valley.
\end{abstract}

Keywords: groundwater recharge; water management; storm management; water storage facilities; Guadalupe Valley

\section{Introduction}

Around the world, groundwater constitutes approximately $94 \%$ of the total volume of freshwater, making it the most reliable drinking water supply, thus providing a wide range of economic and environmental service [1]. Therefore, groundwater is a vital resource for socioeconomic sustenance, as well as for the supply of urban and rural areas [2], as there is an increasing water demand as a result of rapid industrialization and population growth [3].

The intensive extraction of groundwater exceeds the natural recharge in several arid and semi-arid areas of the world [4]; in addition to this, one of the greater threats of the twenty-first century is the change in weather patterns [5]. It is worth mentioning that the increase in temperature plays a crucial role, since it alters the availability of water and generally increases the intensity of droughts and their impacts. 
Groundwater recharge is driven by several soil properties such as infiltration capacity, stochastic characteristics of rainfall, and other climatic variables. In addition, the spatial and temporal distributions of rainfall are the main factors that control the natural groundwater recharge. In semi-arid regions, the recharge is irregular and occurs only in periods of heavy rain [6]. Many factors affect the occurrence and movements of groundwater in a region, including topography, lithology, geological structures, fracture extension, the primary and secondary porosity, gradient, drainage patterns, land use and soil type, and the weather $[7,8]$.

Rainfall infiltration and the contribution of rivers and lakes recharge the aquifers in a natural way; therefore, the protection of these areas is important for the well-being of the aquifers. The use of aquifers to manage and store water is not a new idea, and it has already been implemented in several areas around the world. It is an important tool for the sustainable management of groundwater and the recovery of aquifer depletion. It is important to understand the groundwater resource situation, which is crucial to evaluate the threat with regards to soil salinity, degrading crop production, and land subsidence, which are mainly induced by the over-pumping of groundwater under the inadequate water supply condition [9].

The management of groundwater resources has emerged as an exceedingly important concern; an increasing demand for groundwater in agriculture, domestic and industrial uses ranks it as a resource of strategic importance. Global estimates show that approximately $4430 \mathrm{~km}^{3}$ of freshwater resources are abstracted annually, of which $70 \%$ are used in agriculture, $25 \%$ in industry and $5 \%$ in households [10]. On the whole, annual groundwater abstracted across the world can be placed at $750-800 \mathrm{~km}^{3}$, which is about one-sixth of the total freshwater abstraction [11]. In agricultural-based economic regions, the significance of water availability and its management is very important. In order to create sufficient irrigation facilities, attention needs to be focused on groundwater, which is the only viable source of water in such arid areas [12].

On-site geo-hydrological studies, as well as geophysical research, help to explain the process of groundwater recharge and evaluate the spatial and temporal differences in the study area. However, they commonly focus on a single affecting factor, or a specific indirect experiment on the recharge site of the groundwater, which reduces the reliability of explanations. Recently, the usage of remote sensing has been increasing, complementing the exploration and on-site experiments, since it provides a broader scale of space-time distribution of observations and saves time and money $[13,14]$.

Several researchers around the world have carried out remote sensing and the use of geographic information systems (GIS) for the exploration of potential groundwater recharge areas [2]. For example, remote sensing along with GIS for groundwater reveals hidden hydrological characteristics and works with indicative elements on the surface, such as, frequency of drainage, density, lithological characteristics, land use and coverage, etc., offering a better estimation and qualitative evaluation of the potential recharge. Remote sensing, with its advantages of spatial, spectral and temporal availability of data that covers large and inaccessible areas in a short time, has become a fast and profitable tool to evaluate, monitor and preserve groundwater resources. [15].

Most studies evaluating recharge areas with remote sensing and GIS have been carried out in arid and semi-arid regions of developing countries, hence the proposal of a methodology to identify recharge areas by classifying them in general as "good," "moderate," "poor" and "very poor" [16-18]. In America, similar methodologies have been applied. For example, in 2016 Chamorro conducted a study to identify and characterize recharge zones using GIS, finding that the physical variable of the slope of the terrain was the most sensitive to the applied methodology [19]. Herrera-Jiménez, in 2017, identified recharge areas in Ecuador to establish sustainable management strategies [20]. In Mexico, it is challenging to apply these methods, due to the scarcity of information and data used for the identification of recharge areas. Some studies, such as those of Sáenz-López in 2015 [21], and Cruz-Falcón and collaborators in 2011 [22], are among the few that have been carried out in the country. In the State of Baja California, Mexico, groundwater provides around $60 \%$ of the demand and has become an essential source for agriculture, industry and domestic use. However, the rapid growth of 
the population and the lack of sustainable management of water resources will pose a great challenge in the future to preserve food and water security [23]. A study by Gaeta-Lara [24] in 2006 projected an increase in the population with by an average annual rate of $2.08 \%$; by 2030 this would cause a decrease in the available daily liters of water for each habitant from $90 \mathrm{~L}$ to $47 \mathrm{~L}$.

Particularly in the Guadalupe Valley, in the city of Ensenada, the development of diverse activities depends on the availability of the water stored in the aquifer and the intermittent flow in the streams of the Guadalupe Valley [25]. Among them, the wine industry stands out; due to its high value, it represents a local and regional development factor, allowing the recognition of this region on a national level. However, the level of productivity and wine development has been at risk due to the overexploitation of groundwater [24,26]. In general terms, the current extraction of the aquifer is divided into three parts: (1) The extraction carried out by the vineyards; (2) the sum of the extractions from all the other activities in the valley; and (3) the contribution of water for the city of Ensenada [27]. The latter is of great importance since it is the main source of water for public use in the municipality.

The Guadalupe Valley aquifer is recharged during extreme rainfall events through the Guadalupe River, an ephemeral river that empties into the Pacific Ocean [28]. Other studies have shown that the volume of water stored in the aquifer has presented a gradual downward trend. Therefore, in order to guarantee sustainable management, it is necessary to know more precisely the inputs, outputs and water reserves [29,30]. The deficit in the underground levels has caused irregularities in the production of grapes, increasing in some years and decreasing in others. This is related to recent droughts, overexploitation of water, as well as frosts and long periods of heat [31,32].

Several governmental entities have carried out studies to identify the main problems regarding the management of aquifer resources and the creation of action plans to stabilize its water levels. In 2007, the Autonomous University of Baja California, in collaboration with the National Water Commission, created an integrated groundwater management plan. Figures 1 and 2 show the problems identified and their possible action plans. To this date there hasn't been any other management plan for the aquifer [33].

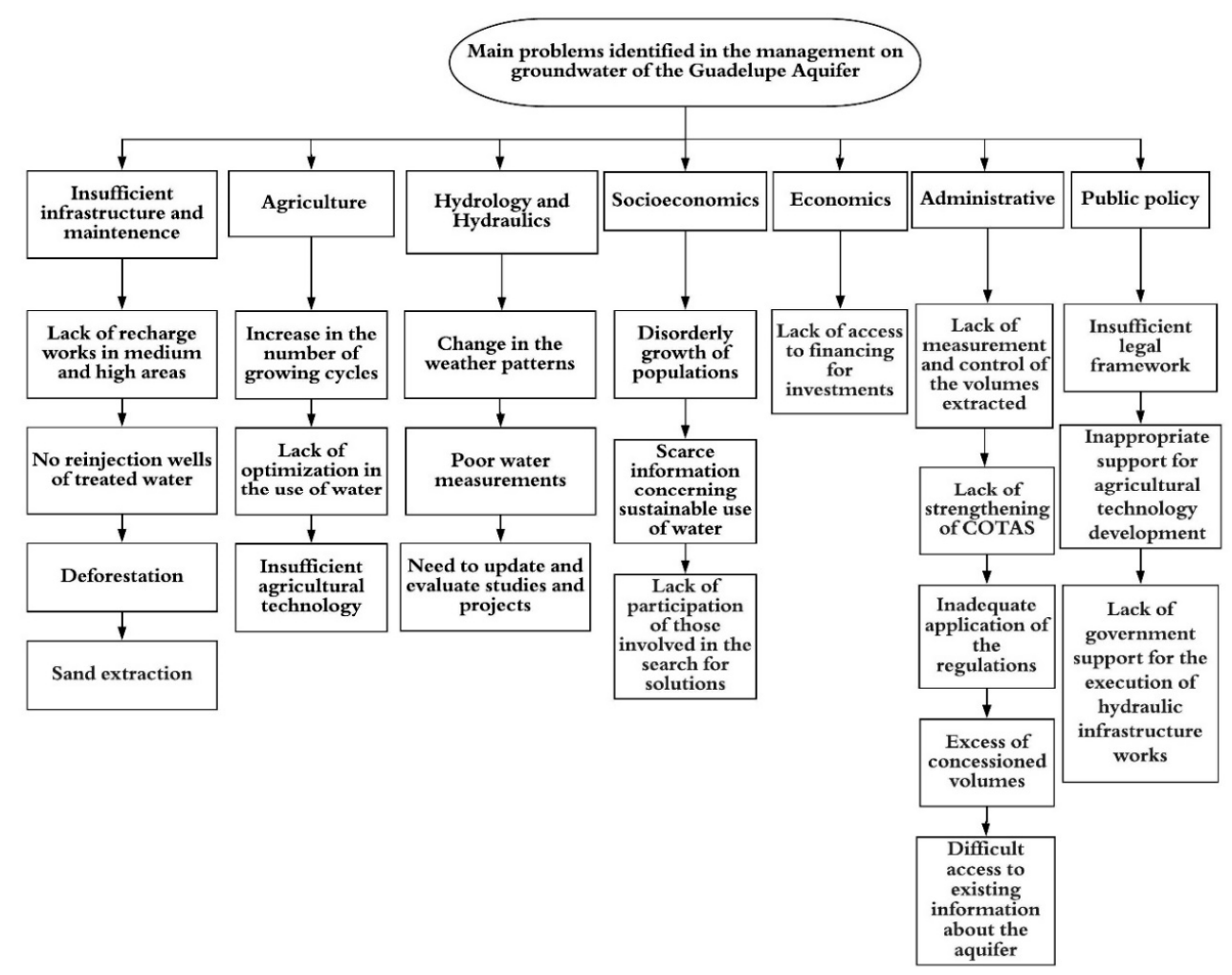

Figure 1. 2007 Groundwater management plan in the Guadalupe Valley aquifer, the issues addressed, and the main problems identified. 


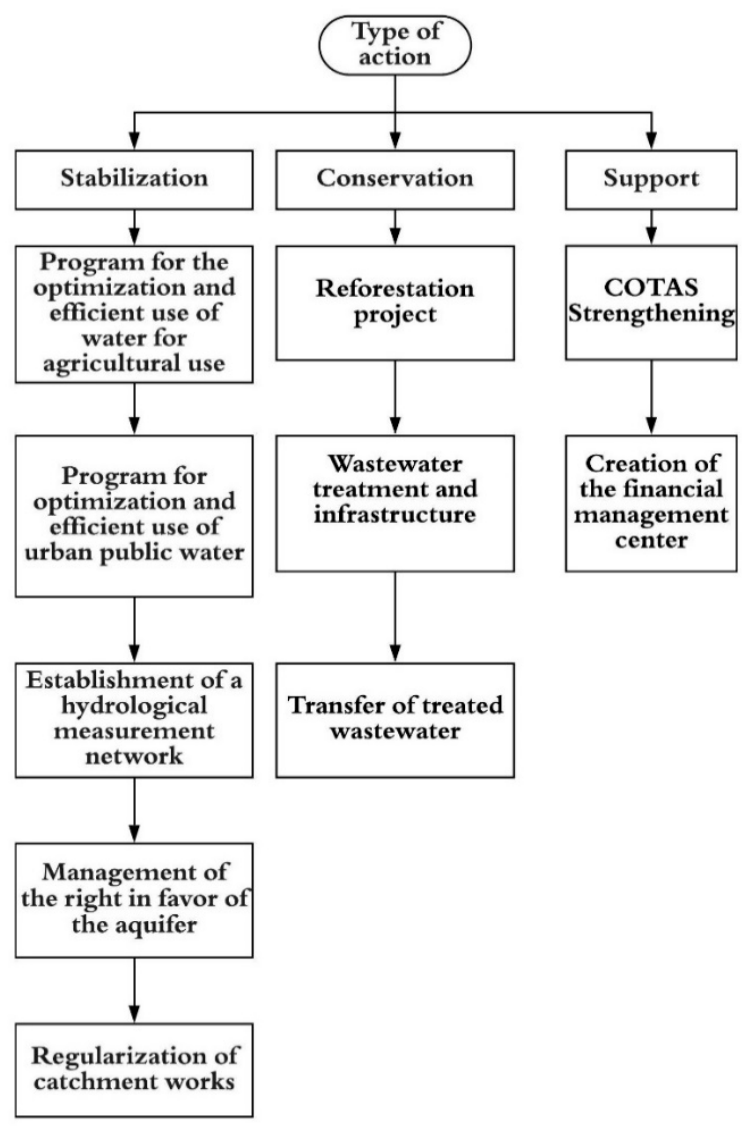

Figure 2. Actions proposed in the 2007 groundwater management plan for the Guadalupe Valley aquifer.

The heterogeneity and cultural diversity of the valley are the main social qualities that should be taken into account for planning the development of this space. In terms of community attributes, the vine cultivation activity has become an area of growth and opportunity, generating businesses that are directly linked to hotels, restaurants, tour operators and stores specializing in wine sales. Regarding the biophysical aspects that structure this sector, the most important issue is the scarcity of water, which is why it is now a circumstantial issue on which the sustainability of its production depends [34]. Therefore, the objective of this study is to identify potential recharge areas in the Guadalupe Valley, which allows the generation of future actions for sustainable management of the water resources in the region.

\section{Materials and Methods}

This research was developed in four fundamental parts, including: (1) Summary and identification of vector data and raster inputs in the recharge model, considering those layers that have been used in similar studies and will be available in the only official database of the country, Instituto Nacional de Estadística Geografía e Informática (INEGI); (2) identification and evaluation of the sites that represent a greater or lesser capacity for groundwater recharge through processing, reclassification and over-positioning of layers, using a geographic information system; (3) comparison of the results of the GIS model with the piezometric data of two wells within the study area, and the current environmental conditions concerning their relationship with the registered precipitation events; (4) finally, the development planning instruments of the study area and the relevance of this study as a planning tool were identified. 


\subsection{Study Area}

This study was developed within the Guadalupe Valley basin, located north of Ensenada municipality, in the State of Baja California, Mexico (Figure 3). This valley is $25 \mathrm{~km}$ from the Pacific Ocean, and it extends over an area of $663.53 \mathrm{~km}^{2}$, in which the Guadalupe River flows [35]. Geographically, Guadalupe Valley is located in the latitude of the wine producing regions, since the weather and soil in these areas are ideal for the best use in the cultivation of the wine grape [36]. Precipitation events are generally intense, obtaining annual averages that can vary from 12 to more than $750 \mathrm{~mm}$, with a historical average of $280 \mathrm{~mm}$. The monthly average temperatures vary between 0.6 to $30^{\circ} \mathrm{C}$ [37]. The physiography of the basin presents elevations between 388 and $1865 \mathrm{~m}$ above mean sea level (MSL), with predominantly intrusive igneous rocks, mainly granodiorite from the Cretaceous.

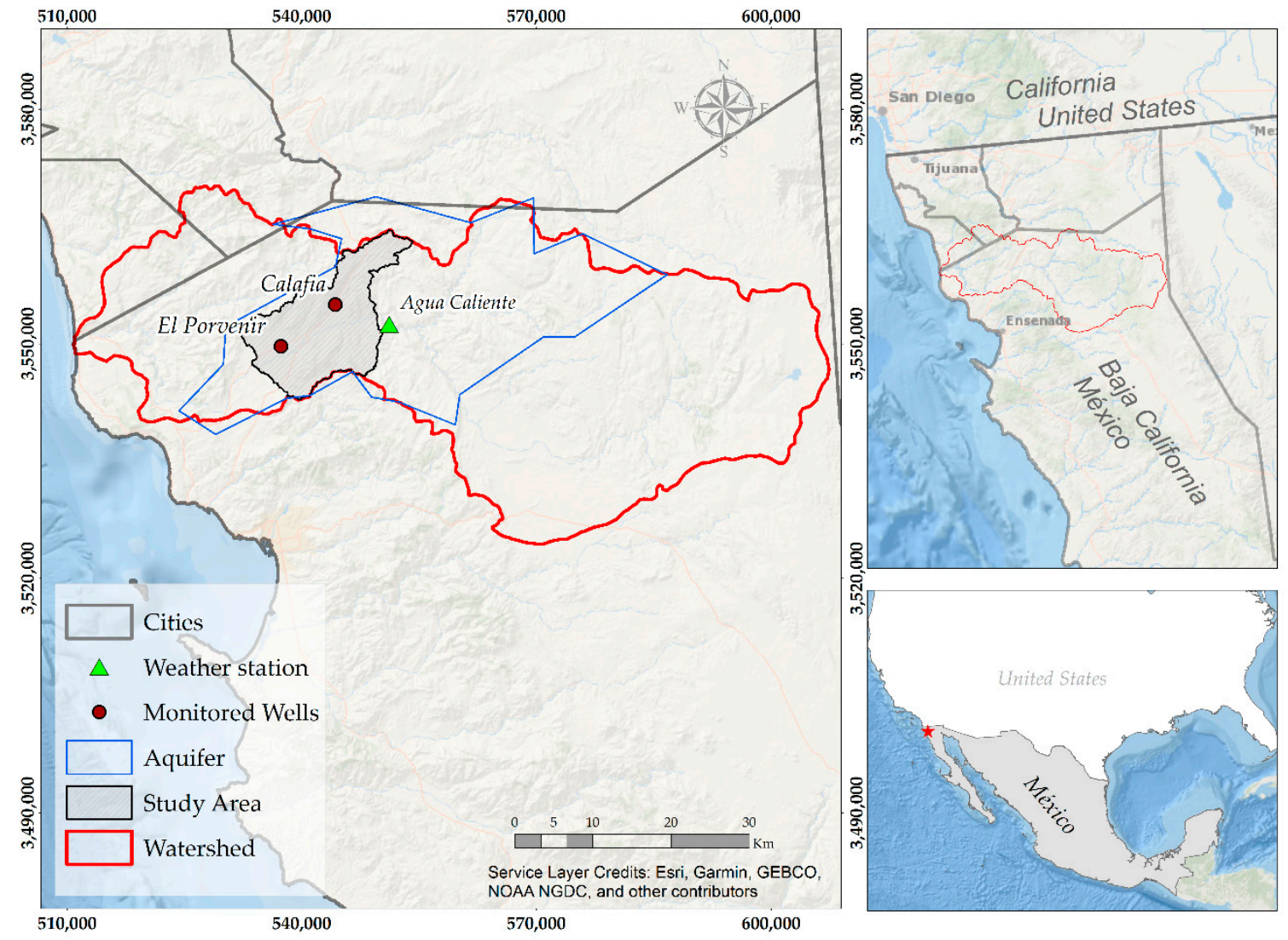

Figure 3. Location of the study area.

According to Ponce et al. [38,39], the infiltration volume equals $10 \%$ of the water precipitated annually in the basin analyzed, estimated based on watershed data pertaining to similar semi-arid climates, physiography and vegetation characteristics, and whose high temperatures caused a high rate of evapotranspiration throughout most of the year.

Hydrogeological studies about the aquifer of the valley are minimal; some of them, such as Andrade [40] and Gonzales-Ramirez [41], suggest that factors of a geological nature intervene importantly in the origin of the aquifer. The various faulting processes that occurred in the study area are responsible for the formation of at least two pits, "Califia" and "el Porvenir," aligned substantially from northeast to southwest, and currently filled with unconsolidated materials as a subsequent product of hauling and deposition [40]. The aquifer is defined as a free aquifer, and its capacity is 218.1 $\mathrm{Mm}^{3}$, considering a static level of $10 \mathrm{~m}$ [41].

The water that the valley uses for irrigation, as well as $30 \%$ of the water supply for the city of Ensenada, comes from the aquifer in its entirety [42]. This allows the economic development of the 
valley, where agriculture mostly prevails, mainly related to the vine and the olive tree [43]; and also provides the water supply to the different users who reside in or visit Ensenada. Official reports made by the Comisión Nacional del Agua (CONAGUA) [29] in 2018 estimated that the annual water balance values of the aquifer are currently in a deficit. At the date the report was published, the average annual recharge was 18.8 million $\mathrm{m}^{3}$. However, the groundwater volume of concessions for extraction was 36.92 million $\mathrm{m}^{3}$; therefore, there is a deficit of approximately 18.22 million $\mathrm{m}^{3}$.

The determination of potential recharge areas was carried out in one of the sub-basins delimited from the runoffs and digital elevation models of the total surface area of the basin. We selected the sub-basin in which the greatest agricultural and economic activity in Guadalupe Valley is carried out and, moreover, is instrumented with monitoring equipment for groundwater levels and meteorological stations. As a result, the study area of the sub-basin analyzed in this study is located in the UTM WGS 1984-Zone 11N: 542,961 m east and 3,552,520 m north, extending over a surface area of $212 \mathrm{~km}^{2}$. Within the delimitation, the elevations range from a minimum of $305 \mathrm{MSL}$ to $1308 \mathrm{MSL}$, generating slopes of up to 55 degrees. The predominant soil cover in this area is Chaparral, with an area of $141.36 \mathrm{~km}^{2}$, equivalent to $67 \%$ of the total area. Regarding agriculture, this extends over an area of $53.67 \mathrm{~km}^{2}$, or $11 \%$ of the total area of the sub-basin.

\subsection{Recharge Model}

Taking as a reference several studies and the data availability, the following factors were selected as input data for the generation of the map of potential recharge areas: (1) Density of drainage and slopes-these layers were generated from a digital elevation model (DEM); (2) use-coverage of the soil and vegetation; (3) coverage of soil type. In addition, the rainfall data and elevation levels of the groundwater were analyzed in order to corroborate that there was recharge in the identified areas. The methodology followed for processing the data is presented in Figure 4.

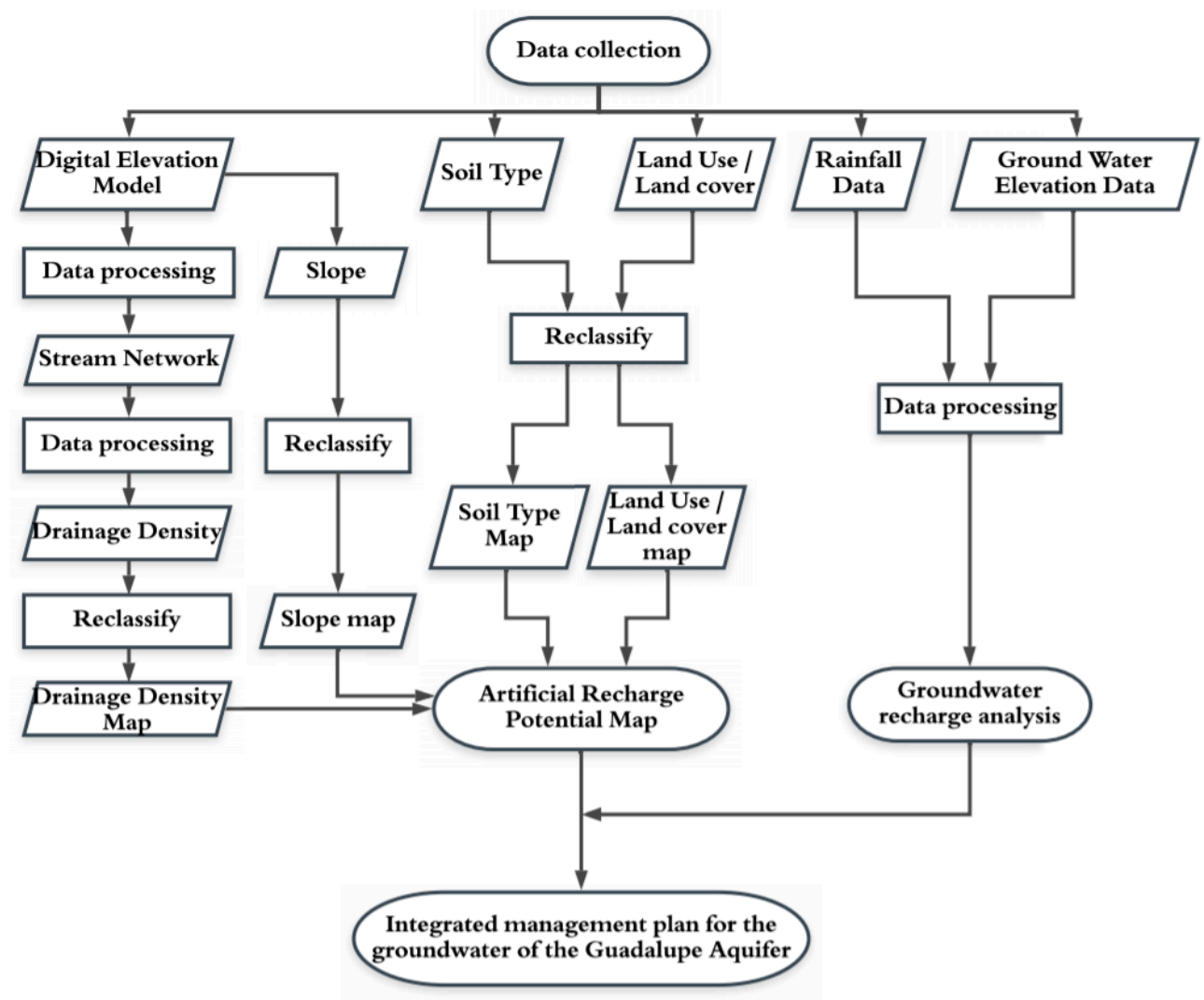

Figure 4. Flow chart of the methodology used in the study to delineate potential artificial recharge areas. 


\subsubsection{Input Data}

The input of data collected for the model of potential recharge areas were obtained from the official Mexican database, created by the INEGI; by its name in Spanish, on the website https: //www.inegi.org.mx. A digital elevation model (DEM) with a resolution $15 \times 15 \mathrm{~m}$ was used together with the GIS tools to generate the network of surface runoff (Figure 5). Subsequently, the results obtained were used to calculate the drainage density of the sub-basin, applying the formulation of Greenbaum, 1985 [44]:

$$
\mathrm{Dd}=\frac{\sum_{i=1}^{i=n} S i}{A}
$$

where $\sum_{i=1}^{i=n} S i$ defines the total length of the drain, and $A$ represents the total area of the sub-basin. This part of the model is fundamental, since the drainage density relates the total stream length with a determined area; therefore, a high drainage density implies low levels of percolation in the soil [18].
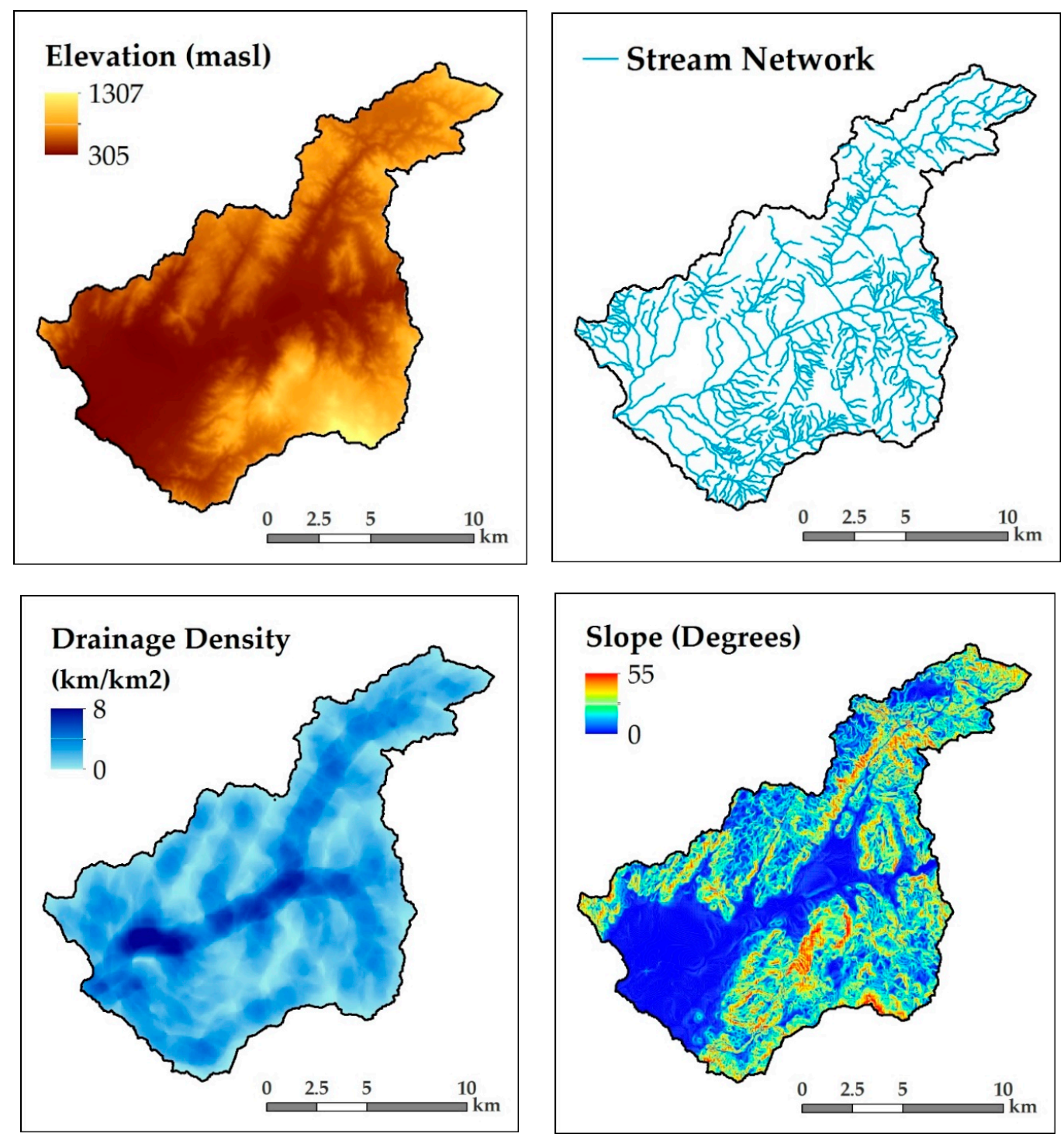

Figure 5. Geographic information system (GIS) processing of the digital elevation model (DEM) of Instituto Nacional de Estadística Geografía e Informática (INEGI) used to obtain the network layers of runoff, drainage density, and slopes. 
Considering the fact that the research area presents elevations that vary from 305 to $1308 \mathrm{MSL}$, a slope layer of the sub-basin was generated using the same DEM. Generally, slope is a variable that is not often used in studies related to storage if the study area does not have mountainous surfaces [45]. However, it should be mentioned that a "valley" is described as a plain between mountains, or a depression of the earth's surface between two slopes, with an incline and elongated shape which forms a watershed, in whose bottom a fluvial course is housed-in our case, the Guadalupe Valley. However, the presence of surface water in the main channel of our study area commonly manifests during extreme precipitation events. Therefore, where higher slopes are present, runoff speeds increase, thus generating a low recharge potential. Areas with lower slopes will have lower speeds and consequently higher recharge.

Agriculture is the economic activity that prevails in the Guadalupe Valley. It covers an area of approximately $53.67 \mathrm{~km}^{2}$ and includes mainly grape vine and olive tree cultivation, as well as the cultivation of other crops in lower proportions, such as those of carob, plum, apricot, peach, mandarin, quince, walnut, and grapefruit. [41]. Currently, in the communities of Francisco Zarco, El Porvenir, El Tigre, and San Antonio de las Minas, around 47 companies exist dedicated to grape vine cultivation and wine production. In the last ten years, the industry has experienced a significant growth [46]. These constant changes alter the amount of groundwater recharge [47].

Due to the sensitive nature of land use and soil type, in terms of their ability to potentially alter groundwater recharge, in this study, those data were used as input layers for the model. They were obtained from the databases of INEGI at a scale of 1:250,000 (Figure 6). It is worth mentioning that the properties and faults of rocks have an important influence on recharge; sediments, such as alluvium, are considered the material with the highest recharge potential in areas with limited slope, while their igneous counterparts provide the lowest contribution of recharge, due to their impermeability. Faults and fractures were also used by computing the Euclidean distance. Finally, urban areas were not considered, as they do not contribute to recharge.
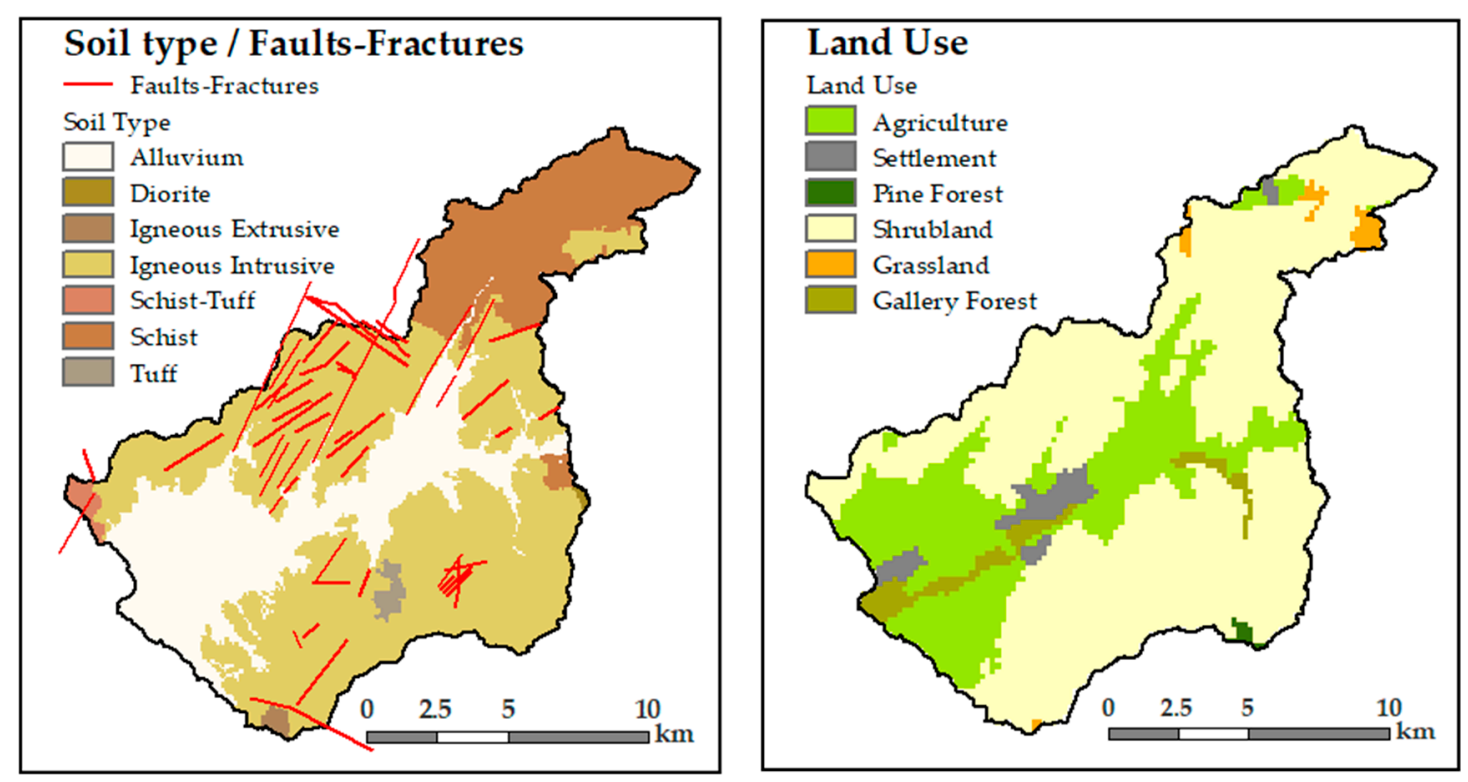

Figure 6. Lithological and land use maps of the study area.

\subsubsection{Reclassification}

The input data used in the model to identify potential recharge areas, also referred to by some authors, such as Magesh [2], Senanayake [3] and Yeh [17], as the influencing factors, were: Slope, land use, lithology and drainage density. The layers of each of these variables were classified in GIS and assigned a weight, as shown in Table 1 . These data were calculated by averaging the values of the 
weights obtained in previous studies where similar methods have been implemented in GIS with the multi-influencing factors (MIF) technique, taking into consideration the characteristics of the study site and according to the interrelation between these characteristics. For example, the layers with greater weights were those with more influence compared to other factors [48]. Not all the input data in the model had the same influence in the determination of the potential groundwater recharge areas. However, they were dependent on each other [18]; therefore, a value was assigned to allow the evaluation and identification of the calculated recharge areas. Subsequently, the layers were reclassified with their assigned weights; and finally, by adding the weight of all the layers, a map was obtained in which the potential recharge areas are delimited.

Table 1. Reclassification and recharge contribution of the influencing factors.

\begin{tabular}{|c|c|c|c|}
\hline Factor & Value & Reclassification & Recharge Contribution \\
\hline \multirow{5}{*}{ Slope } & $>20$ & 0 & Very low \\
\hline & $15-20$ & 3 & Low \\
\hline & $10-15$ & 6 & Medium \\
\hline & $5-10$ & 8 & High \\
\hline & $<5$ & 10 & Very high \\
\hline \multirow{5}{*}{ Land Use } & Settlement & 0 & Very low \\
\hline & Pine forest & 2 & Low \\
\hline & Grassland & 3 & Medium \\
\hline & $\begin{array}{c}\text { Shrubland and } \\
\text { Bush }\end{array}$ & 4 & High \\
\hline & Agriculture & 7 & Very high \\
\hline \multirow{5}{*}{ Lithology } & Igneous rocks & 0 & Very low \\
\hline & Sedimentary rocks & 2 & Low \\
\hline & Metamorphic rocks & 3 & Medium \\
\hline & Lineaments & 8 & High \\
\hline & Alluvium & 10 & Very high \\
\hline \multirow{5}{*}{$\begin{array}{l}\text { Drainage density } \\
\qquad\left(\mathrm{km} / \mathrm{km}^{2}\right)\end{array}$} & $3-8$ & 0 & Very low \\
\hline & $2-3$ & 2 & Low \\
\hline & $1-2$ & 3 & Medium \\
\hline & $0.5-1$ & 5 & High \\
\hline & $0-0.5$ & 7 & Very high \\
\hline
\end{tabular}

The MIF methodology for identifying potential groundwater recharge areas was adapted for the proposal of potential groundwater recharge areas (Table 2). It consists of assigning weights of 1 and 0.5 to the major and minor influence effects, respectively, among the factors, and the accumulated weight represents a relative rate $(\mathrm{A}+\mathrm{B})($ Table 3$)$ that is used to calculate the influence score of each factor with the formula:

$$
\frac{(\mathrm{A}+\mathrm{B})}{\sum(\mathrm{A}+\mathrm{B})}
$$

Table 2. Estimations of recharge influence among layers.

\begin{tabular}{ccccc}
\hline Factor/Influence & Slope (Sl) & Land Use (Lu) & $\begin{array}{c}\text { Soil Type (St), } \\
\text { Faults }\end{array}$ & $\begin{array}{c}\text { Drainage Density } \\
\text { (Dd) }\end{array}$ \\
\hline Slope & & 0.5 & 1 & 1 \\
Land use & 1 & & $0.5,0.5$ & 1 \\
Soil type & 1 & & 0.5 & 1 \\
Drainage density & 1 & & 0 & \\
\hline
\end{tabular}


Table 3. Influencing effects by recharge potential factor.

\begin{tabular}{ccccc}
\hline Factor & A & B & A + B & $\begin{array}{c}\text { Proposed } \\
\text { Influencing Factor }\end{array}$ \\
\hline Slope & $1+1$ & 0.5 & 2.5 & 0.28 \\
Land use & $1+1$ & $0.5+0.5$ & 3 & 0.33 \\
Soil type & $1+1$ & & 2 & 0.22 \\
Drainage density & 1 & 0.5 & 1.5 & 0.17 \\
& & & $\sum 9$ & $\sum 1$ \\
\hline
\end{tabular}

The final Potential of Artificial Recharge (PAR) map was calculated as:

$$
\text { PAR: } 0.28 \mathrm{SI}+0.33 \mathrm{Lu}+0.22 \mathrm{St}+0.17 \mathrm{Dd}
$$

where $\mathrm{Sl}$ is the Slope, Lu is Land use, St is the Soil Type and Dd is Drainage density.

\subsection{Analysis of Precipitation and Recharge}

Data monitoring and observation wells around the aquifer are sparse; however, an analysis of the response of the aquifer water level to precipitation events was made from 2014 to 2015 in order to relate and assess the existence of recharge in the mapped recharge zones.

The aquifer was monitored by the Comité Técnico de Aguas Subterráneas of Guadalupe Valley, (COTAS, by its initials in Spanish) (http://cotas.comtitec.com); to this date only eight pressure sensors are installed in different observation wells; however, most of them present gaps or intermittent data. A monitored well inside the Calafia pit, at coordinates 544,296.96 m east and 3,555,005.98 m north, and one at the El Porvenir pit, at coordinates 537,334.04 m east and 3,549,669.00 m north, are the only ones with a continuous collection of data presently.

Precipitation data were provided by the climate monitoring network of the National Water Commission, CONAGUA (https://www.gob.mx/conagua) and were retrieved from the Agua Caliente weather station registered at coordinates $551,182.51 \mathrm{~m}$ east and 3,552,480.16 m north.

\section{Results}

The map of potential recharge areas in the Guadalupe Valley aquifer shows the spatial distribution of the five categories, defined according to their specific weights and characteristics (Figure 7). Surfaces with a high and very high recharge potential extend mainly in agricultural areas composed of alluvial material and with slopes of less than 10 degrees. On the other hand, the areas with medium, low or very low recharge potential were found on surfaces with shrubs, soils composed of igneous rocks and schists, and slopes between 11 and 36 degrees. The areas without recharge-excluding sites where human settlements are present-occurred in impermeable rocky sites with slopes higher than 36 degrees.

It is estimated that the Guadalupe Valley sub-basin represents a total area of $143.27 \mathrm{~km}^{2}(67.5 \%$ of the basin area) of areas with recharge potential. However, zones with a low recharge potential predominate, which extend across $49.39 \mathrm{~km}^{2}(23.26 \%)$ of the studied area. The zones with very high recharge were present only across $7.72 \mathrm{~km}^{2}(4 \%)$, and were those with the least spatial coverage. The surface results, by category, with their percentages are shown in Table 4. It should be mentioned that the demarcation of these zones-mainly with a potential recharge of high or very high — could be used as a tool for decision makers, with which they should define the appropriate sites to build the hydraulic infrastructure that allows recharging of the aquifer. In addition, this will promote the sustainable management of water resources in the Guadalupe Valley, which will allow the continuation of its agricultural development with the production of grapes. 


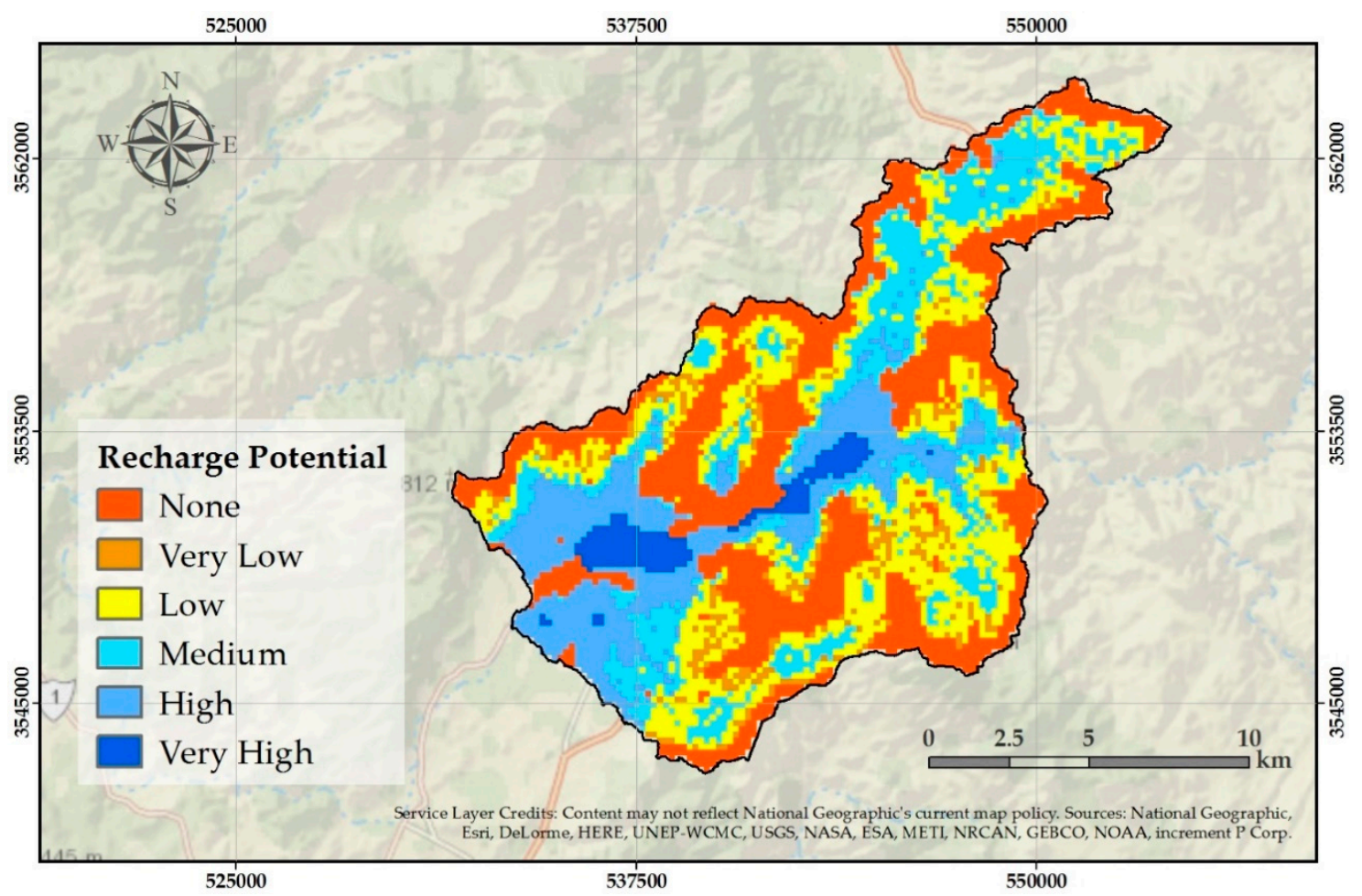

Figure 7. Map of potential recharge areas obtained in GIS.

Table 4. Areas and percentages of the spatial distribution per type of recharge zone.

\begin{tabular}{ccc}
\hline Recharge Potential & Area $\left.\mathbf{( k m}^{\mathbf{2}}\right)$ & Percentage $\mathbf{( \% )}$ \\
\hline None & 68.99 & 32.50 \\
Very Low & 11.45 & 5.40 \\
Low & 49.37 & 23.26 \\
Medium & 40.10 & 18.89 \\
High & 34.63 & 16.31 \\
Very High & 7.72 & 3.64 \\
& $\sum 212.26$ & $\sum 100$ \\
\hline
\end{tabular}

The moderate slopes in the settlements of the Guadalupe Valley slow down and increase the time at which the water is in contact with the ground, favoring recharge. However, the wine industry in this region has developed in adverse conditions due to: The overexploitation of the groundwater, which represents its perennial only source of water supply; the semi-arid weather that is typical of the northwest region of Mexico, causing prolonged droughts that have affected agricultural production; the exploitation of sand in streams, which increases the evaporation of water; and also attempts to change the uses of agricultural land, which threatens to increase hydric stress [49].

In accordance to the data from the Agua Caliente weather station, a total of $108.41 \mathrm{~mm}$ of rain was registered during 2014-2015, with mostly isolated events ranging from 0.3 to $21.4 \mathrm{~mm}$. Precipitation events, mainly during February to May, were reflected in the recharge of the static levels in the Calafia and El Porvenir trenches (Figure 8). However, in the Calafia trench this behavior was more effective, since during the rainfall of $21.4 \mathrm{~mm}$ in March the water level increased from 323.50 to 324.27 MSL $(0.77 \mathrm{~m})$; meanwhile, in the El Porvenir trench, the levels varied from 306.84 to $306.90 \mathrm{MSL}$ (0.06 m). 

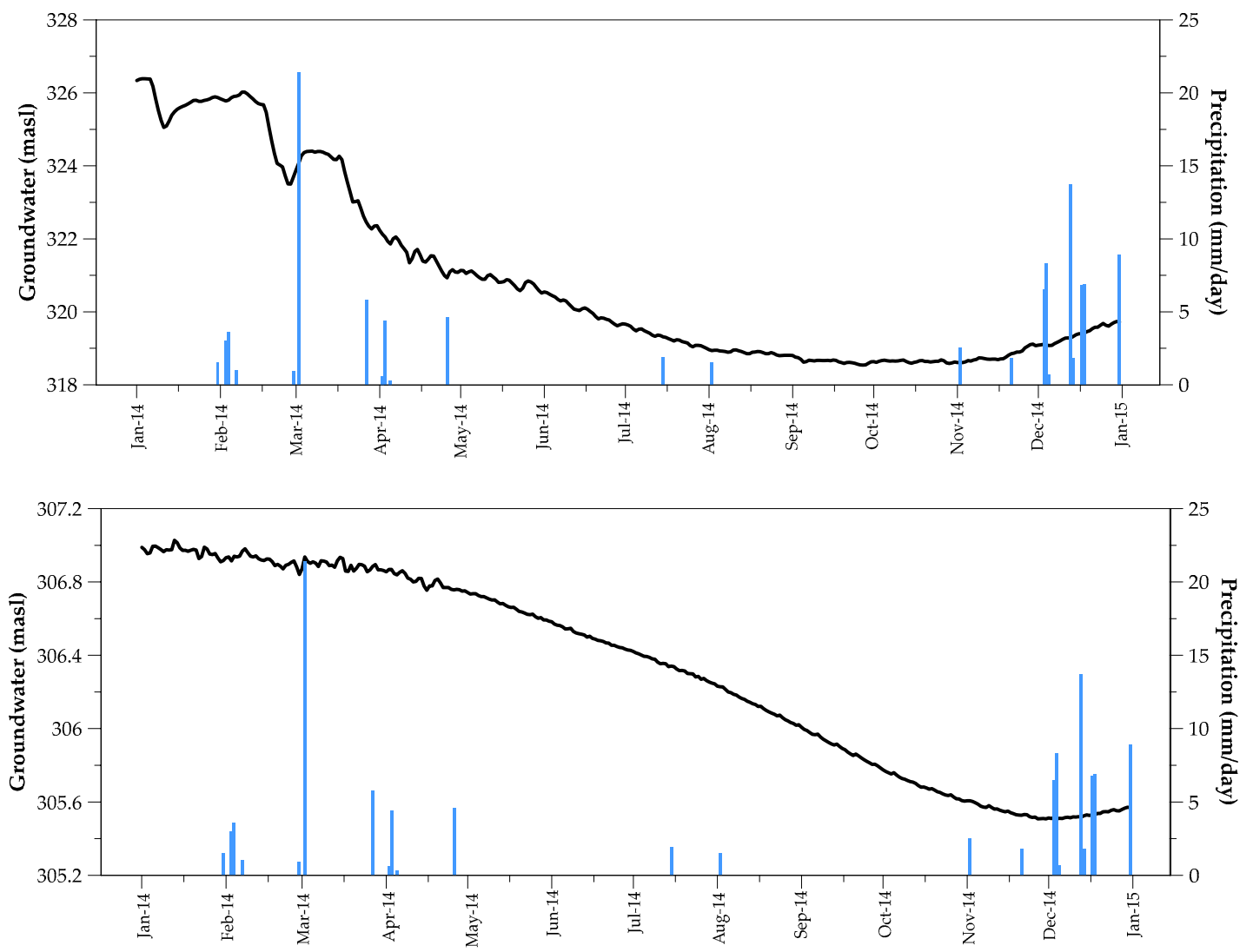

Figure 8. Behavior of the static levels in the wells located in the Calafia (above) and El Porvenir (below).

\section{Discussion}

The main limitations of this work were the lack of previous studies, and the quality and quantity of data, hence the time period chosen in the study for the recharge analysis. Although this analysis is not considered a proper validation, it is the first approach to address the existence of recharge in the zones marked as very high and high for ground water recharge potential.

Regarding the results of the maps, there are a few points that must be discussed. The land use and soils on these areas with surface water sources were found to be suitable for recharge. Also, since the infrastructure will be constructed by farmers and not by government or prominent stakeholders, small green infrastructure is the ideal solution. For example, the design of treatment wetlands for water recharge. This infrastructure is commonly designed for small runoff areas, like creeks in moderate slopes with the appropriate soil type.

Most of the areas on the resulting map that were identified as high or very high for potential recharge zones, correspond to lands owned by companies dedicated to the cultivation of vines and the production of wine. Proposing infrastructure to promote recharge in these private areas is challenging; however, farmers in the Guadalupe Valley are concerned about the decrease in the available volume of water for irrigation and the water quality, which helps them to sustain their standards of an internationally recognized product. For these reasons, they are prepared to invest in these sustainable practices. Especially when considering that there is insufficient infrastructure, and the existing infrastructure is badly located.

A future improvement on this study could be the refinement of soil and land use layers. Since the available scale of these layers in the study area is 1:250,000, using a lower scale such as 1:50,000, since this is available for other regions of the country, could significantly improve the obtained results and the delineation of more potential recharge zones.

In addition, there are no studies or reports that define the limits in both trenches. However, due to the difference in water levels registered in this study $(\approx 20 \mathrm{~m})$, and due to the response times to local 
precipitation events, it was corroborated that the aquifer is composed of two independent underground water systems. The measurements in the wells indicate that the natural recharge is not enough to mitigate the effects of overexploitation, since even during this period part of the historical depletion of the Guadalupe Valley aquifer was observed, derived from the rapid growth and tourism demand in the region.

Water recharge was also observed during December 2014 to January 2015, but with a gradual increase in both wells, which was also a product of the decrease in the volumes of water extracted for the irrigation of crops, as well as low levels of evapotranspiration. On the other hand, the water levels did not result in significant recharge during the month of May, and from then until the end of October, since only two rain events were witnessed: One of $1.9 \mathrm{~mm}$ in July and another of $1.5 \mathrm{~mm}$ in August. Despite the observation of the presence of recharge in both wells, their behavior differs with the results obtained through the mapping in GIS, since it was observed that the well located in the Calafia trench is located within an area with high recharge potential and the El Porvenir well is located in an area with very high recharge potential (Figure 7). The identification of the high and very high recharge areas can be delimited with the proposed methodology in an efficient way where conditions favor infiltration, such as high drainage density, low slopes, vegetation coverage, and low urban equipment. On the other hand, the sensitivity of the recharge model shows that the slope of the terrain has a great influence when generating the map, due to the geomorphological conditions of the site. The obtained result shows that the type of soil and the slope have an important role in the recharge potential map; in the same way, they are the factors that have great influence in the material recharge and, together with overexploitation, they do not allow the aquifer to recover during rains.

Usually, when modeling or assessing water resources from sparse or lacking data, the issue is addressed by using remote sensing tools such as layers, models, or other networks. Some of these can provide climate data such as precipitation or evapotranspiration. However, when it comes to groundwater data, there is a minimal set of tools useful to address the lack of data and groundwater level monitoring. Regardless of all the limitations of the study, its main objective, the delineation of recharge zones, is fulfilled. What is limited is the recharge volume of each of the identified zones. Future instrumentation projects should focus on the monitoring of these zones to assess its real recharge rates.

\section{Conclusions}

The methodology of using overlay layers in GIS, integrating the parameters of slope, drainage density, soil type, and land use, allowed us to generate the first identification map of potential recharge areas in the Guadalupe Valley. The weight assigned to each layer derived from the processes and information available; therefore, the analysis may have had an effect on the accuracy of the results, since it was subject to the availability and accuracy of the thematic layers of the region. The result obtained and their validation depend on the availability and quality of official information, which is a limitation in our country. However, it proved to be an efficient and appropriate methodology in the context of saving time and costs for a region where short-term actions are required due to hydric stress, as evidenced by an analysis in the observation well records, and precipitation levels.

The map obtained could allow for artificial recharge to be encouraged in the face of the evident depletion of the aquifer and the low recharge during precipitation events. The results of this study show that the implemented methodology can be used for the proposal and planning of recharge infrastructure, and can be used for monitoring in the observation wells regarding the effects of the evident overexploitation as a tool for sustainable management of the water resource.

The methodology can serve as a guideline for planning and future artificial recharge projects in the Guadalupe Valley. As noted in Figures 1 and 2, there have been efforts to assess action plans and solutions to the management problem of the aquifer. However, due to lack of study or resources those projects were yet to develop. This study can help to focus actions in the identified zones, making them more affordable, since they are limited to a determined area. 
Some factors that disfavor recharge, such as the high slopes and urban areas, were discarded for the generation of the artificial recharge map, leaving the free areas and the proximities to the main sources of surface water, as those conducive to recharge infrastructure. It should be noted that on a smaller scale, proposing an adequate artificial recharge infrastructure will require field and laboratory studies for the analysis and integral decision in the region. However, the map resulting from this study will serve as a precedent for future works on sustainable water management at different scales.

The activities within the Guadalupe Valley complicate the natural recharge of the aquifer due to the alterations that the natural vegetation cover has suffered. These are the consequences of intensive land use in agricultural production, affecting the natural properties of the water system of the aquifer. However, these altered surfaces are considered within the map as potential recharge zones due to the availability of water and the possibility of reusing the irrigation water and collecting rainwater in the agricultural area. There is also the opportunity to involve the activities of the valley in the development of a sustainable management measure, generating a social and tourist attraction in search of an emblematic and sustainable valley that provides socioeconomic benefits to the region and its inhabitants.

Developing countries in arid regions have the problems of a lack of and sparsity of monitoring data. Often, the issue is addressed by using remote sensing tools such as layers, models, or other networks. The few infrastructure and instrumentation investments have to be back up by previous studies since they are limited. The results of studies like this provide a guide or tool for investors and governments in other arid or semiarid regions of developing countries to focus the limited available budget in areas or zones where a real result is expected, since there has been a previous mapping.

Author Contributions: J.A.S.-R. methodology, software, writing-review and editing, investigation; M.A.L.B. investigation validation data curation, writing — review and editing; C.S.-B. writing—original draft preparation; J.M.R.-G. investigation, writing — original draft preparation; A.M.-M. supervision, project administration.

Funding: This research received no external funding.

Acknowledgments: We sincerely appreciate the Universidad Autónoma de Baja California, Comité Técnico de Aguas Subterraneas del Valle de Guadalupe, and the Universidad de Sonora, for their support in this study.

Conflicts of Interest: The authors declare no conflict of interest.

\section{References}

1. Robinson, M.; Ward, R. Principles of Hydrology; McGraw-Hill: New York, NY, USA, 1990.

2. Magesh, N.; Chandrasekar, N.; Soundranayagam, J.P. Delineation of groundwater potential zones in Theni district, Tamil Nadu, using remote sensing, GIS and MIF techniques. Geosci. Front. 2012, 3, 189-196. [CrossRef]

3. Senanayake, I.; Dissanayake, D.; Mayadunna, B.; Weerasekera, W. An approach to delineate groundwater recharge potential sites in Ambalantota, Sri Lanka using GIS techniques. Geosci. Front. 2016, 7, 115-124. [CrossRef]

4. FAO. The State of the World's Land and Water Resources for Food and Agriculture (SOLAW) Managing Systems at Risk; Food and Agriculture Organization of the United Nations: Rome, Italy, 2011.

5. $\quad$ Bernstein, L.; Bosch, P.; Canziani, O.; Chen, Z.; Christ, R.; Riahi, K. IPCC, 2007: Climate Change 2007: Synthesis Report; IPCC: Geneva, Switzerland, 2008.

6. Şen, Z. Applied Drought Modeling, Prediction, and Mitigation; Elsevier: Amsterdam, The Netherlands, 2015.

7. Mukherjee, S. Targeting saline aquifer by remote sensing and geophysical methods in a part of Hamirpur-Kanpur, India. Hydrogeol. J. 1996, 19, e64.

8. Jaiswal, R.; Mukherjee, S.; Krishnamurthy, J.; Saxena, R. Role of remote sensing and GIS techniques for generation of groundwater prospect zones towards rural development-An approach. Int. J. Remote Sens. 2003, 24, 993-1008. [CrossRef]

9. Tangdamrongsub, N.; Han, S.-C.; Tian, S.; Müller Schmied, H.; Sutanudjaja, E.H.; Ran, J.; Feng, W. Evaluation of groundwater storage variations estimated from GRACE data assimilation and state-of-the-art land surface models in Australia and the North China Plain. Remote Sens. 2018, 10, 483. [CrossRef] 
10. Kinzelbach, W.; Bauer, P.; Siegfried, T.; Brunner, P. Sustainable groundwater management—Problems and scientific tool. Epis. Newsmag. Int. Union Geol. Sci. 2003, 26, 279-284.

11. Shah, T. Groundwater Markets and Agricultural Development: A South Asian Overview; Pakistan Water Partnership: Islamabad, Pakistan, 2000.

12. Chenini, I.; Mammou, A.B.; El May, M. Groundwater recharge zone mapping using GIS-based multi-criteria analysis: A case study in Central Tunisia (Maknassy Basin). Water Resour. Manag. 2010, 24, 921-939. [CrossRef]

13. Murthy, K. Ground water potential in a semi-arid region of Andhra Pradesh-a geographical information system approach. Int. J. Remote Sens. 2000, 21, 1867-1884. [CrossRef]

14. Tweed, S.O.; Leblanc, M.; Webb, J.A.; Lubczynski, M.W. Remote sensing and GIS for mapping groundwater recharge and discharge areas in salinity prone catchments, southeastern Australia. Hydrogeol. J. 2007, 15, 75-96. [CrossRef]

15. Suresha, K.J. Delineation of Groundwater Potential Zones in the Mudugunduru Sub Watershed, Mandya District, Using Remote Sensing and GIS. Int. J. Innov. Res. Sci. Eng. Technol. 2016, 48. [CrossRef]

16. Machiwal, D.; Jha, M.K.; Mal, B.C. Assessment of groundwater potential in a semi-arid region of India using remote sensing, GIS and MCDM techniques. Water Resour. Manag. 2011, 25, 1359-1386. [CrossRef]

17. Yeh, H.F.; Cheng, Y.S.; Lin, H.I.; Lee, C.H. Mapping groundwater recharge potential zone using a GIS approach in Hualian River, Taiwan. Sustain. Environ. Res. 2016, 26, 33-43. [CrossRef]

18. Shaban, A.; Khawlie, M.; Abdallah, C. Use of remote sensing and GIS to determine recharge potential zones: The case of Occidental Lebanon. Hydrogeol. J. 2006, 14, 433-443. [CrossRef]

19. Chamorro, M. Identificación y Caracterización de las zonas de Recarga Hídrica Mediante Herramientas SIG de los acuíferos La Carbonería, Guaraczapas, Yuyucocha Y Santa Clara para la Protección de las Fuentes de Aprovisionamiento de agua en la zona Urbana de Ibarra; Univ. Técnica Norte Ibarra: Ibarra, Ecuador, 2016.

20. Herrera Jiménez, K.F. Identificación hidrológica de zonas de recarga de las fuentes de abastecimiento de agua en la comuna la Esperanza, provincia del Carchi. Bachelor's Thesis, Universidad Técnica del Norte, Ibarra, Ecuador, 2017.

21. Sáenz-López, Á.A.; Bravo-Peña, L.C.; Torres-Olave, M.E.; Alatorre-Cejudo, L.C. Localización de zonas con Potencial Natural de Recarga Hídrica: Ensayo de Enfoque Multiescalar en el Acuífero Cuauhtémoc. 2015. Available online: https://www.researchgate.net/publication/302511670_Localizacion_de_zonas_con_ potencial_natural_de_recarga_hidrica_ensayo_de_enfoque_multiescalar_en_el_acuifero_Cuauhtemoc (accessed on 26 February 2019).

22. Cruz-Falcón, A.; Vázquez-González, R.; Ramírez-Hernández, J.; Nava-Sánchez, E.H.; Troyo-Diéguez, E.; Rivera-Rosas, J.; Vega-Mayagoitia, J. Precipitación y recarga en la cuenca de La Paz, BCS, México. Univ. Cienc. 2011, 27, 251-263.

23. Emami, F.; Koch, M. Agricultural water productivity-based hydro-economic modeling for optimal crop pattern and water resources planning in the Zarrine River Basin, Iran, in the wake of climate change. Sustainability 2018, 10, 3953. [CrossRef]

24. Gaeta Lara, A. Productividad de la vid en Función del Aprovechamiento de agua Subterránea en el Valle de Guadalupe 1994-2004. MPA Thesis, Centro de Investigación Cientıfica y de Educación Superior de Ensenada (CICESE), Ensenada, Mexico, 2006.

25. Kurczyn-Robledo, J.A.; Kretzschmar, T.; Hinojosa-Corona, A. Evaluación del escurrimiento superficial en el noreste del Valle de Guadalupe, BC, México, usando el método de curvas numeradas y datos de satélite. Rev. Mex. Cienc. Geológicas 2007, 24, 1-14.

26. Ruiz, L.M.; Martínez, J.A.V.; Radillo, S.E.M. La Ruta del Vino en el Valle de Guadalupe, Baja California, México. Perspectiva frente al Cambio climático: Una Primera Aproximación. 2012. Available online: https://www.researchgate.net/profile/Sonia_Maldonado-Radillo/publication/262449906_La_Ruta_del_ Vino_en_el_Valle_de_Guadalupe_Baja_California_Mexico_Perspectiva_frente_al_cambio_climatico_Una_ primera_aproximacion/links/00b49537bae3bc732b000000/La-Ruta-del-Vino-en-el-Valle-de-GuadalupeBaja-California-Mexico-Perspectiva-frente-al-cambio-climatico-Una-primera-aproximacion.pdf (accessed on 26 February 2019). 
27. Badán, A.; Kretzschmar, T.; Espejel, I.; Cavazos, T.; D’Acosta, H.; Vargas, P.; Mendoza, L.; Leyva, C.; Aramburo, G.; Daessle, W.; et al. Hacia un plan de manejo del agua en Valle de Guadalupe, Baja California. Memorias del II Seminario Internacional de Vitivinicultura: Ensenada, Baja California, México. INIFAP 2006, 45-64.

28. Campos-Gaytan, J.R.; Kretzschmar, T.; Herrera-Oliva, C.S. Future groundwater extraction scenarios for an aquifer in a semi-arid environment: Case study of Guadalupe Valley Aquifer, Baja California, Northwest Mexico. Environ. Monit. Assess. 2014, 186, 7961-7985. [CrossRef] [PubMed]

29. Comisión Nacional del Agua (CONAGUA). Actualización de la disponibilidad media anual de agua en el acuífero de Guadalupe (204), Estado de Baja California. In Diario Oficial de la Feración; Secretariat of the Interior: Mexico City, Mexico, 2018; Available online: https://sigagis.conagua.gob.mx/gas1/Edos_Acuiferos_ 18/BajaCalifornia/DR_0207.pdf (accessed on 14 January 2019).

30. Comité Técnico de Aguas Subterraneas del Valle de Guadalupe (COTAS del Valle de Guadalupe) Actualización de la red de Monitoreo Piezométrica del Acuífero de Guadalupe. 2012. Available online: http://cotas.comtitec. com/uploads/docs/actualizacion_piezometria_noviembre_2012.pdf (accessed on 14 January 2019).

31. Bodenstendt Engel, A. Art Boden Mexican Wine Guide; Grupo Editorial M\&M, SA de CV: México City, Mexico, 2008.

32. Meraz, L. Diseño de una Estrategia de Mercadotecnia Para una Pequeña Empresa Vitivinícola en Ensenada, Baja California. Unpublished Ph.D. Thesis, Universidad Autónoma de Baja California, México City, Mexico, 2009.

33. Secretaría de Protección al Ambiente. 2016 Programa Ambiental Estratégico de la región vitivinícola de Valle de Guadalupe, Municipio de Ensenada, Baja California, México city, Mexico. Gobierno del Estado de Baja California, 2016. Available online: http://www.spabc.gob.mx/wp-content/uploads/2018/ 05/PROGRAMA-AMBIENTAL-ESTRATEGICO-DE-LA-REGION-VITIVINICOLA-DEL-VALLE-DEGUADALUPE-MUNICIPIO-ENSENADA-B.C.-2016-1.pdf (accessed on 4 March 2019).

34. Celaya, D. El Desarrollo del Sector Vitivinícola en Baja California (2000-2013): Un Análisis Desde la Perspectiva del Desarrollo Endógeno. Colegio de la Frontera Norte, 2014. Available online: https: //www.colef.mx/posgrado/wp-content/uploads/2014/11/TESIS-Celaya-Tentori-Diana-DCSER.pdf (accessed on 5 March 2019).

35. Espejel, I.; Fischer, D.W.; Hinojosa, A.; García, C.; Leyva, C. Land-use planning for the Guadalupe Valley, Baja California, Mexico. Landsc. Urban Plan. 1999, 45, 219-232. [CrossRef]

36. Amey, R. Wines of Baja California: Touring and Tasting Mexico's Undiscovered Treasures; Board and Bench Publishing: San Francisco, CA, USA, 2004.

37. Hallack-Alegria, M.; Ramirez-Hernandez, J.; Watkins, D. ENSO-conditioned rainfall drought frequency analysis in northwest Baja California, Mexico. Int. J. Climatol. 2012, 32, 831-842. [CrossRef]

38. Ponce, V.M.; Pandey, R.P.; Kumar, S. Groundwater recharge by channel infiltration in El Barbon basin, Baja California, Mexico. J. Hydrol. 1999, 214, 1-7. [CrossRef]

39. Kresic, N. Quantitative Solutions in Hydrogeology and Groundwater Modeling; CRC Press: Boca Raton, FL, USA, 1997; 461p.

40. Andrade Borbolla, M. Actualización geohidrológica del Valle de Guadalupe, Municipio de Ensenada, Baja California; Grupo Agroindustrial del Valle de Guadalupe: Ensenada, Baja California, México, 1997; 60p.

41. González Ramírez, J. Monitoreo y Modelado de la Respuesta del nivel Freático ante Eventos de Precipitación en el Acuífero de Valle de Guadalupe, B.C. MPA Thesis, Centro de Investigación Cientıfica y de Educación Superior de Ensenada (CICESE), Ensenada, Mexico, 2013.

42. Salgado, T. El uso de Tecnologías de la Información en el Desarrollo de un plan de Manejo Sustentable del Acuífero del Valle de Guadalupe, BC. Ph.D. Thesis, Colegio de Postgraduados, Montecillo, Mexico, 2010.

43. Sánchez Zepeda, L. Localización Territorial y Organización Productiva de la Industria Vinícola del Valle de Guadalupe. Aproximación a la Incidencia de la Industria Vinícola en el Desarrollo Económico del Valle de Guadalupe (México) y La Manchuela (España). Unpublished Ph.D. Thesis, Universidad de Castilla-La Mancha, Ciudad Real, España, 2007.

44. Greenbaum, D. Review of Remote Sensing Applications to Groundwater Exploration in Basement and Regolith. 1985. Available online: http://nora.nerc.ac.uk/id/eprint/505150/1/WC_OG_85_1.pdf (accessed on 8 March 2019). 
45. Al Saud, M. Mapping potential areas for groundwater storage in Wadi Aurnah Basin, western Arabian Peninsula, using remote sensing and geographic information system techniques. Hydrogeol. J. 2010, 18, 1481-1495. [CrossRef]

46. López, V.; Sotelo, C. Los vinos del Valle de Guadalupe: Análisis de su comercialización. Eur. Sci. J. 2014, 10, 90-106.

47. Leduc, C.; Favreau, G.; Schroeter, P. Long-term rise in a Sahelian water-table: The Continental Terminal in south-west Niger. J. Hydrol. 2001, 243, 43-54. [CrossRef]

48. Yeh, H.F.; Lee, C.H.; Hsu, K.C.; Chang, P.H. GIS for the assessment of the groundwater recharge potential zone. Environ. Geol. 2009, 58, 185-195. [CrossRef]

49. Leyva Aguilera, J.A.; Espejel Carbajal, M.I. El valle de Guadalupe. Conjugando Tiempos. Universidad Autonoma de Baja California. 2013. Available online: https://ciencias.ens.uabc.mx/documentos/libros/ LibroValleGuadalupe.pdf. (accessed on 20 February 2019).

(C) 2019 by the authors. Licensee MDPI, Basel, Switzerland. This article is an open access article distributed under the terms and conditions of the Creative Commons Attribution (CC BY) license (http://creativecommons.org/licenses/by/4.0/). 